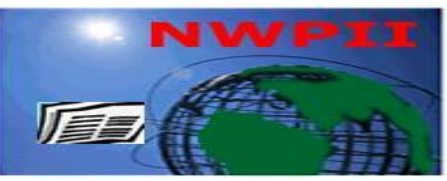

American Journal of Biomedical Sciences

ISSN: 1937-9080

nwpii.com/ajbms

\title{
Dose Related Relationship of Depleted Uranium Associated with Certain Blood Electric Properties
}

\author{
Mamdouh M. Shawki * and Abdel-Rahman M. Hereba
}

Medical Bio-Physics Department, Medical Research Institute, Alexandria University, Egypt.

*Corresponding author:

Mamdouh M. Shawki

Medical Bio-Physics Department

Medical Research Institute

Alexandria University

165 Alhorya Avenue, Alhadara

Alexandria, Egypt

Tel: $+2(03) 4285455$.

Fax: +2(03)4283719

E-mail: mamdouh971@hotmail.com.

Received: 8 March 2014; | Revised: 8 May 2014; | Accepted: 30 May 2014

\begin{abstract}
In many radiation applications, there are clear dose effect relationships. On the other hand, there are many confusions about the radiation dose relationship that comes from depleted uranium on blood. Time study (0-16 hours) of three concentrations of uranyl acetate (1, 2 and $4 \mathrm{mM})$, which can reflect radiation dose multiplications, is used as depleted uranium on stored human blood. The exposed blood dielectric properties were measured using the three frequencies method at 25, 500 and $1000 \mathrm{KHz}$; the three doses at the different time intervals were compared. We find that some electric properties are not affected by increasing the dose during the whole time interval. No significant changes in neither the cell interior resistance nor in relative permittivity at 25,500 and $1000 \mathrm{KHz}$ at all the time interval, thus no dose relationship can be detected from them. The significant changes in plasma resistance, cell membrane capacitance and dielectric loss (at 25, 500 and $1000 \mathrm{KHz}$ ) are at only 9 hours of exposure and are dose related while there is no significant change at any other time interval. So we conclude that some electric properties if measured at certain time of exposure can give dose related relationship of depleted uranium on blood.
\end{abstract}

Keywords: Depleted uranium, Electric properties, Radiation dose relationship, Blood, Time interval study.

\section{Introduction}

Uranium (U) is a heavy metal naturally present in rocks and surface water. Its use in nuclear power reactors and nuclear weapons has led to questions about its potential toxicity. Most human contamination risks by ingestion come from naturally U-rich soils as well as U mining and processing [1]. The $U$ which remains after 
the removal of enriched fraction is known as depleted Uranium (DU). Although DU is less radioactive compared to natural $\mathrm{U}$, it has the same chemical behavior as natural U [2].

Interest in DU researches is rapidly increasing due to its potential use. DU is used in military applications as anti-tank armor penetrators and as tank armor, as well as in many civilian applications as counterweights in airplane construction, shields for irradiation units in hospitals, and containers for transport of radioactive sources. Small quantities of DU are used also in the formation of porcelains, glasses, and as catalysts [3].

The military and the civilian uses of DU have environmental and health implications and the most important toxic mechanism that is suggested for DU toxicity is the involvement of oxidative stress and reactive oxygen species [4].

Uranyl acetate is usually made from DU and is prepared by reacting metallic uranium with acetic acid. Uranyl acetate is extensively used as a negative stain in electron microscopy. Most procedures in electron microscopy for biology require its use; negative staining protocols typically treat the sample with $1 \%$ to $5 \%$ of its aqueous solution. Uranyl acetate is both radioactive and toxic. Normal commercial stocks prepared from it have a typical radioactivity of $0.37-0.51 \mu \mathrm{Ci} / \mathrm{g}$ [5].

The major sources of DU exposure, and thus the sources available for absorption and distribution in most individuals exposed to DU, are inhalation or ingestion of DU-containing compounds, and in many cases an interaction between the DU and the blood takes place [6].

To our knowledge no data regarding the effects of DU on human hematological parameters has been reported. Some researches involving the experimental animals found effects on some blood parameters but without any dose related effect [7-9], while dose related relationship has been obtained in other organs such as kidney [10].

In the current study we aim to find dose related relationship through time interval study of the electric properties of the blood mixed with DU as well as the reasons of dose effect confusions. We think that absence of dose related effect in the previous studies is because the blood parameters measurements for all the exposed groups may be performed at the deadline at which all the doses may produce the reaction end-products with the blood parameters, so that no significant changes occur between the different doses.

Erythrocytes, like all body cells, possess electrical properties which arise from their membrane structure and intra- and extra- cellular contents. Dealing with radiation effects at the electrical level may have some benefit in defining the effects of radiation as well as in the proposal of possible treatments. We select the blood electric properties to be the dose effect indicator because several studies investigated the sensitivity of the dielectric parameters to the physiological and structural states of erythrocytes, which resulted in the introduction of fitted equations to obtain viscosity [11] and ATP, $\mathrm{K}, \mathrm{Na}$ and $\mathrm{Cl}$ concentrations [12] from dielectric measurements.

\section{Materials and Methods}

\subsection{Blood Sample}

We used $285 \mathrm{~mL}$ heparinzed blood obtained from and analyzed by the blood bank, Medical Research Institute, Alexandria University, Egypt. Blood donation was completely voluntary. The blood bank tested the blood samples against infectious viruses and confirmed that the blood is safe to work with as well as all its components are in the normal range. The blood was divided into 19 groups (each group was repeated in triplet), all the blood group samples having equal volumes $(5 \mathrm{~mL})$.

\subsection{Uranyl acetate}

We decided to work with a concentration of $1 \mathrm{mM}$ uranyl acetate (i.e. $424 \mathrm{mg} / \mathrm{L}$ ) because it has been reported to induce cell death of rat proximal tubule and human kidney cells at least after $16 \mathrm{~h}$ of culture [13]. $2 \mathrm{mM}$ and $4 \mathrm{mM}$ samples were also prepared.

\subsection{Exposed samples}

Six group samples of blood were mixed with $1 \mathrm{mM}$ uranyl acetate for the time intervals 3 
hours (hrs), 6 hrs, 9 hrs, 12 hrs, 14 hrs and 16 hrs. Six group samples of blood were mixed with $2 \mathrm{mM}$ uranyl acetate while other six group samples were mixed with $4 \mathrm{mM}$ for the same time intervals. One unmixed group sample with uranyl acetate served as control. Each blood group after mixture with uranyl acetate is fixed in smooth shaker at air conditioned room with fixed temperature $\left(20 \mathrm{C}^{\mathbf{o}}\right)$ during its time of exposure.

\subsection{Measuring cell}

Two Platinum square electrodes each of 5 $\mathrm{cm}^{2}$ surface area (A) placed at distance (d) of 1 $\mathrm{cm}$ from each other was fixed on opposite walls of the plastic vessel in which the blood samples were measured.

\subsection{Dielectric measurement}

Directly after the exposure time of each group, the blood sample measuring cell was connected to LCR meter (Fluke corporation, Model: PM6306, Germany). To prevent any disturbance in the measurements it was ensured that there is no strong magnetic or electric field in the place where the LCR is placed. Capacitance (C) and resistance (R) of the blood were measured at three dominant frequencies $(25,500$ and $1000 \mathrm{KHz}$ ) according to three frequencies (f) calculation method of [14]. The measured results were displayed on high quality LCD monitor with decimal points and units with accuracy of $0.05 \%$. The blood can be represented by the following circuit:

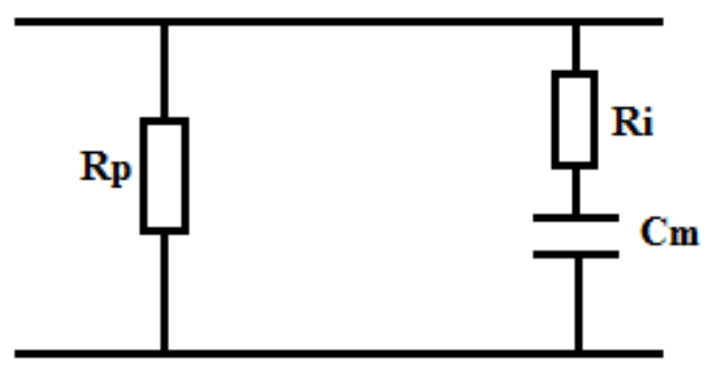

Figure 1. Three-element model of blood. $\mathrm{R}_{\mathrm{p}}$ represents plasma resistance, $R_{i}$ is cell interior resistance and $C_{m}$ is cell membrane capacitance.

The values of the three elements $R_{p}, R_{i}$ and $\mathrm{C}_{\mathrm{m}}$ can be determined by measuring the impedances across the circuit at three different frequencies [14]. The impedance of the circuit is calculated as:

$Z(\omega)=\mathrm{R}_{\mathrm{p}}\left(\frac{\left(1+\omega^{2} \mathrm{C}_{\mathrm{m}}{ }^{2} \mathrm{R}_{\mathrm{i}}{ }^{2}\right)}{1+\omega^{2} \mathrm{C}_{\mathrm{m}}{ }^{2}\left(\mathrm{R}_{\mathrm{p}}+\mathrm{R}_{\mathrm{i}}\right)^{2}}\right)^{\frac{1}{2}}$.

If three impedance amplitudes $Z\left(\omega_{0}\right), Z\left(\omega_{1}\right)$, $\mathrm{Z}\left(\omega_{2}\right)$ at different frequencies $\omega_{0}, \omega_{1}$ and $\omega_{2}$ respectively are measured, the three elements can be obtained as:

$$
\begin{aligned}
& \mathrm{R}_{\mathrm{p}}=\mathrm{K}_{\mathrm{o}}^{\frac{1}{2}} \mathrm{Z}\left(\omega_{\mathrm{o}}\right) \\
& \mathrm{R}_{\mathrm{i}}=R_{p} /\left\{\frac{\left[\left\{\mathrm{K}_{\mathrm{o}}\left[K_{1}-\mathrm{K}_{\mathrm{o}}-F_{1}\left(1-\mathrm{K}_{\mathrm{o}}\right)\right]\right.\right.}{\left[K_{1}-\mathrm{K}_{\mathrm{o}}-F_{1} K_{1}\left(1-\mathrm{K}_{\mathrm{o}}\right)\right]^{\frac{1}{2}}}\right\}^{\frac{1}{2}}-1 \\
& C_{m}=\left(\frac{1}{\omega_{o}}\left\{\frac{\left(1-K_{o}\right)}{\left[K_{o} R_{i}{ }^{2}-\left(R_{p}+R_{i}\right)^{2}\right]}\right\}\right)^{\frac{1}{2}}
\end{aligned}
$$

where

$$
\begin{gathered}
F_{1}=\left(\frac{\omega_{1}}{\omega_{o}}\right)^{2} \\
F_{2}=\left(\frac{\omega_{2}}{\omega_{o}}\right)^{2} \\
K_{1}=\left[\frac{Z\left(\omega_{1}\right)}{Z\left(\omega_{o}\right)}\right]^{2} \\
K_{2}=\left[\frac{Z\left(\omega_{2}\right)}{Z\left(\omega_{o}\right)}\right]^{2} \\
K_{o}=\frac{F_{1} K_{2}\left(1-K_{1}\right)\left(1-F_{2}\right)-F_{2} K_{1}\left(1-K_{2}\right)\left(1-F_{1}\right)}{F_{1}\left(1-K_{1}\right)\left(1-K_{2} F_{2}\right)-F_{2}\left(1-K_{2}\right)\left(1-K_{1} F_{1}\right)}
\end{gathered}
$$

The real part of the relative permittivity $\varepsilon^{\prime}$ and the imaginary part $\varepsilon^{\prime \prime}$ (the dielectric loss) can be calculated as:

$$
\begin{aligned}
& \varepsilon^{\prime}=\frac{C d}{\varepsilon_{o} A} \\
& \varepsilon^{\prime /}=\frac{\varepsilon^{\prime}}{2 \pi f R C}
\end{aligned}
$$

where, $\varepsilon_{0}$ is the vacuum permittivity which equals $8.85 * 10^{-12} \mathrm{~F} / \mathrm{m}$. 


\subsection{Statistical analysis}

Each value was expressed as mean and standard deviation. One-way analysis of variance (ANOVA) was used to compare each variable in the different studied groups. For all statistical comparisons a value of $p<0.05$ was considered significant.

\section{Results}

\subsection{No dose related leading results}

Figures 2-5 show the reasons why there were no dose-related results found by some authors previously. Figure 2 shows unclear relations of intracellular resistance between the different doses at the time intervals that at 3 hours $2 \mathrm{mM}$ is significantly higher than both $1 \mathrm{mM}$ and $4 \mathrm{mM}$ ( $\mathrm{p}=0.0186,0.0001$ respectively). No significant difference is found between $1 \mathrm{mM}$ and $2 \mathrm{mM}$ at 6 hours while $4 \mathrm{mM}$ is significantly lower than $1 \mathrm{mM}$ and $2 \mathrm{mM}$. At 9 hours; $1 \mathrm{mM}$ is significantly higher than $2 \mathrm{mM}(\mathrm{p}=0.0012)$ and $2 \mathrm{mM}$ is higher than $4 \mathrm{mM}(\mathrm{p}<0.0001)$. No statistical differences between the three doses were observed at 12 hours. At 14 and 16 hours there is no significant difference between $1 \mathrm{mM}$ and $2 \mathrm{mM}$ while $4 \mathrm{mM}$ is lower than 1 and $2 \mathrm{mM}$ at 14 hours $(\mathrm{p}=0.0035)$ and at 16 hours $(\mathrm{p}=$ $0.0006)$.

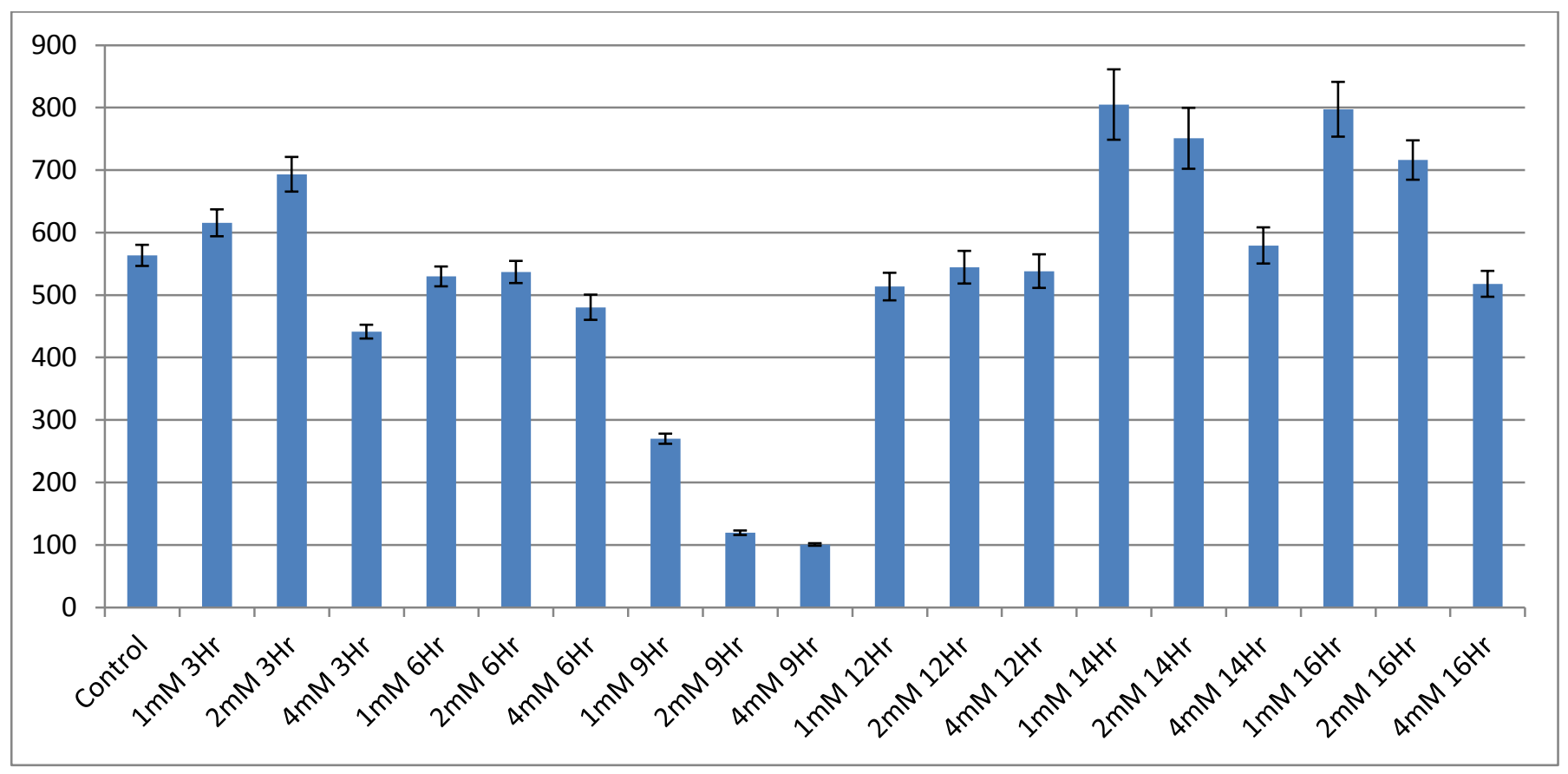

Figure 2. Intracellular resistance $\mathrm{R}_{\mathrm{i}}(\Omega)$ for blood exposed to three different doses of uranyl acetate (1, 2 and $\left.4 \mathrm{mM}\right)$ for time interval $(0-16 \mathrm{Hr})$.

Figures 3-5 show relative permittivity $\left(\varepsilon^{\prime}\right)$ at 25, 500 and $1000 \mathrm{KHz}$ respectively. They show unclear dose relationships at time interval scale; 3 hours $4 \mathrm{mM}$ is significantly higher than $1 \mathrm{mM}$ and $1 \mathrm{mM}$ is higher than $2 \mathrm{mM}$. At 6 hours; there is no significant difference between $1 \mathrm{mM}$ and $4 \mathrm{mM}$ while there is significant decrease for $2 \mathrm{mM}$. $1 \mathrm{mM}$ is very significantly higher than $2 \mathrm{mM}$ while no significant difference is found between $2 \mathrm{mM}$ and $4 \mathrm{mM}$ at 9 hours. $2 \mathrm{mM}$ is significantly higher than $4 \mathrm{mM}$, and $4 \mathrm{mM}$ is significantly higher than $1 \mathrm{mM}$ at 12 hours. At 14 and 16 hours; no significant difference between $1 \mathrm{mM}$ and $2 \mathrm{mM}$ while there is significant decrease of $4 \mathrm{mM}$ compared to other doses. 


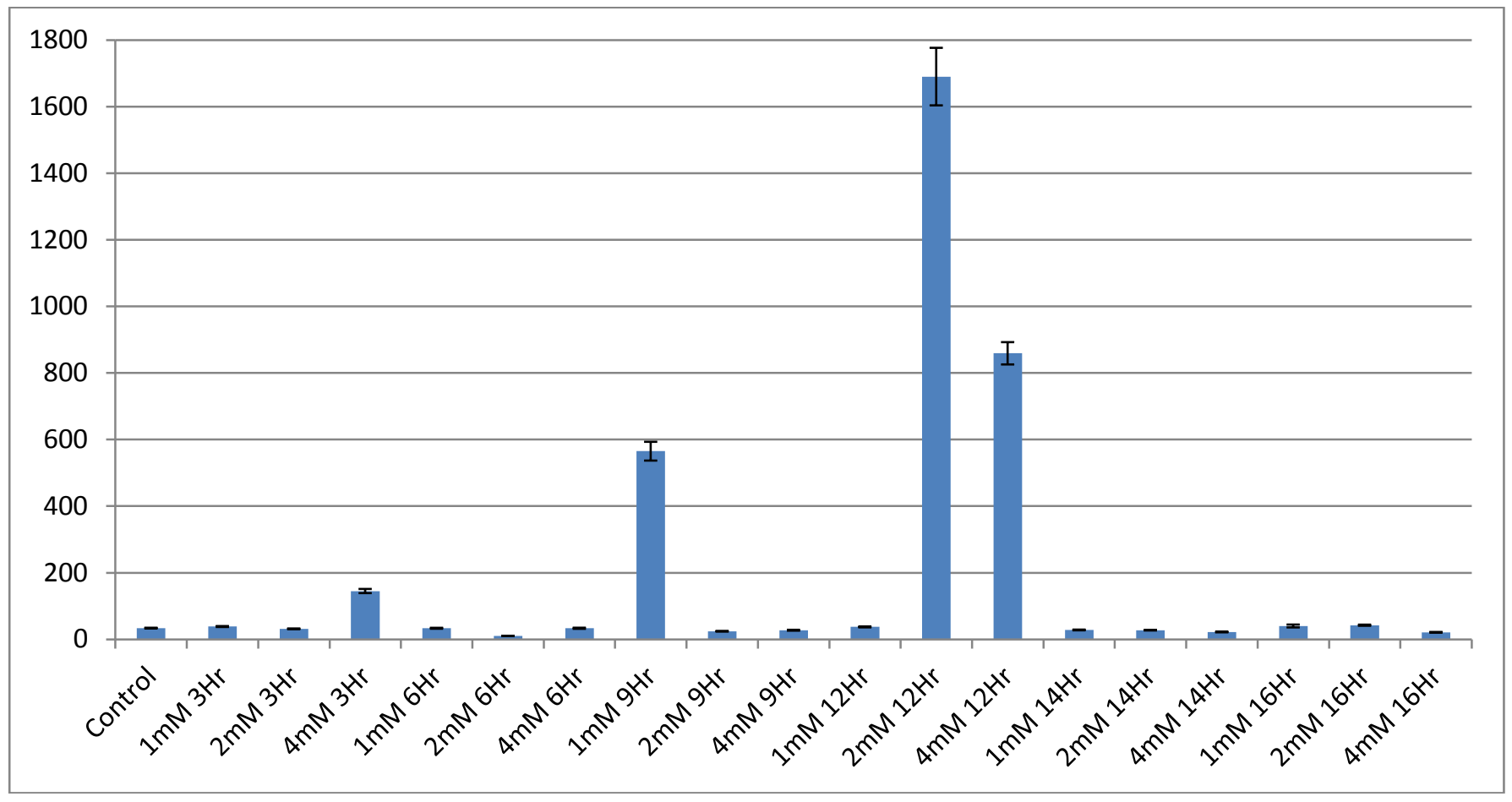

Figure.3. Relative permittivity $\left(\varepsilon^{\prime}\right)$ at $25 \mathrm{KHz}$ for blood exposed to three different doses of uranyl acetate $(1,2$ and 4 $\mathrm{mM})$ for time interval $(0-16 \mathrm{Hr})$.

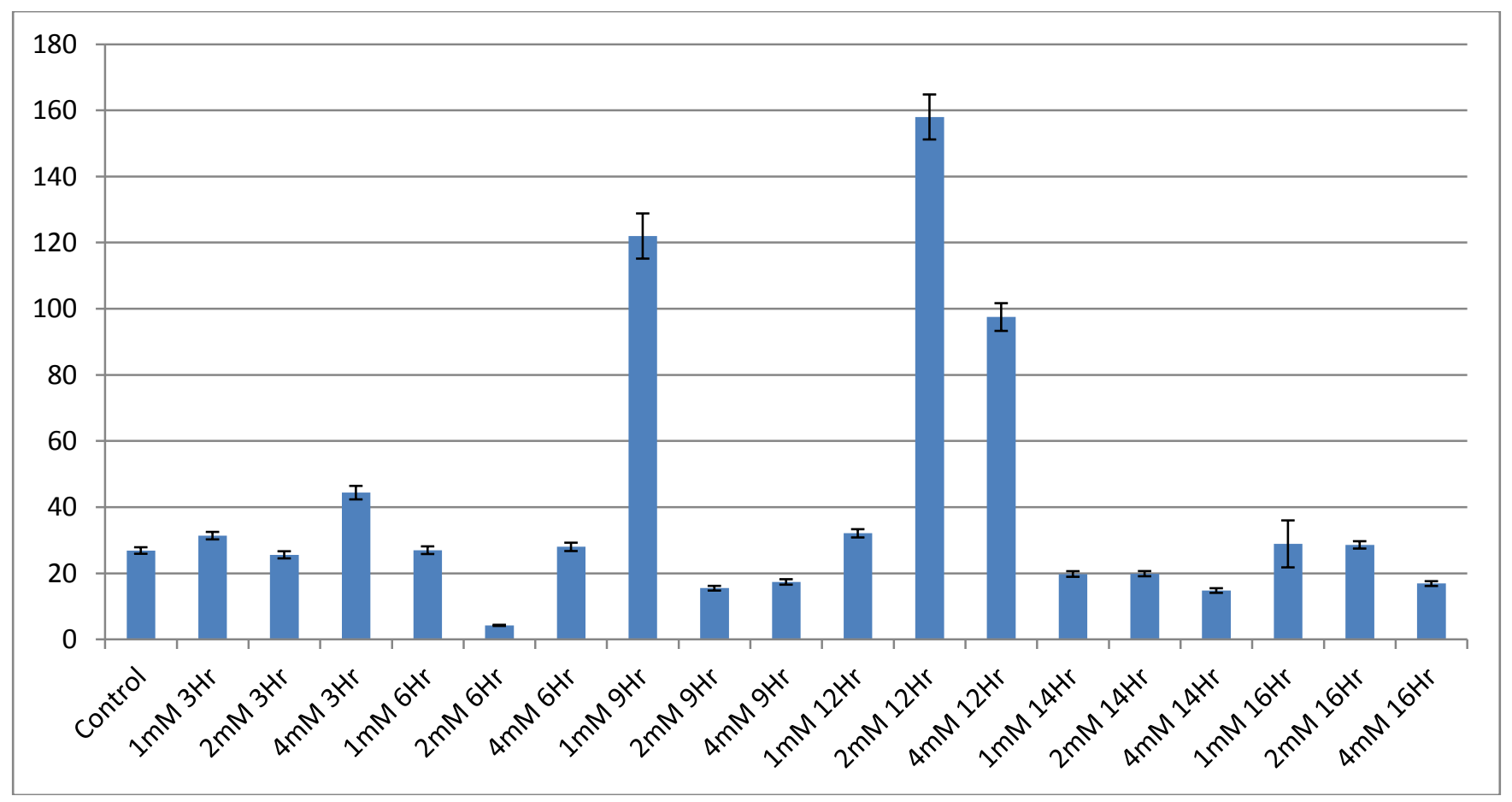

Figure 4. Relative permittivity $\left(\varepsilon^{\prime}\right)$ at $500 \mathrm{KHz}$ for blood exposed to three different doses of uranyl acetate $(1,2$ and 4 $\mathrm{mM})$ for time interval $(0-16 \mathrm{Hr})$. 


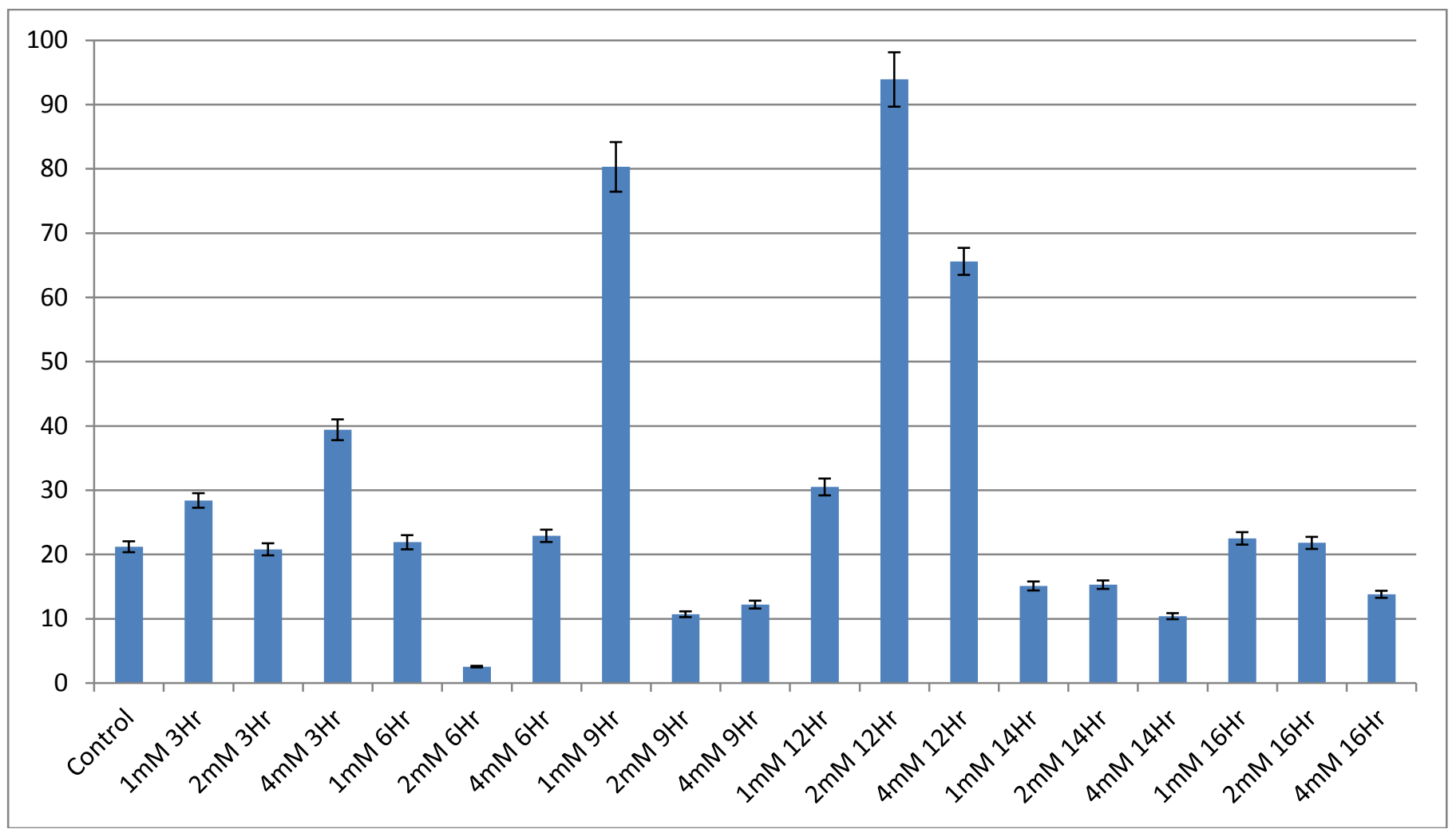

Figure 5. Relative permittivity $\left(\varepsilon^{\prime}\right)$ at $1000 \mathrm{KHz}$ for blood exposed to three different doses of uranyl acetate (1, 2 and $4 \mathrm{mM})$ for time interval $(0-16 \mathrm{Hr})$.

\subsection{Dose related leading results}

Figures 6-10 are the leading parameters that detect the dose effect relationship. Fig. 6 shows no significant results between plasma resistances of the three doses for all time intervals; however, at 9 hours $2 \mathrm{mM}$ is significantly higher than $1 \mathrm{mM}$ $(\mathrm{p}=0.0004)$ and $4 \mathrm{mM}$ is significantly higher than $2 \mathrm{mM}(\mathrm{p}=0.0034)$.

Figure 7 shows no significant differences between plasma resistances of the three doses during the whole time interval with the exception of 9 hours at which $1 \mathrm{mM}$ is significantly higher than $2 \mathrm{mM}$ ( $\mathrm{p}<0.0001)$ and $2 \mathrm{mM}$ is significantly higher than $4 \mathrm{mM}(\mathrm{p}=0.0301)$.
Figures 8-10 show dielectric loss $\left(\boldsymbol{\varepsilon}^{\prime \prime}\right)$ at 25 , 500 and $1000 \mathrm{KHz}$ respectively. They show no significant differences between $\varepsilon^{\prime \prime}$ of the three doses during the whole time interval except at 9 hours. At 9 hours for $25 \mathrm{KHz}, 1 \mathrm{mM}$ is significantly higher than $2 \mathrm{mM}(\mathrm{p}=0.0047)$ and $2 \mathrm{mM}$ is significantly higher than $4 \mathrm{mM}$ ( $\mathrm{p}=$ $0.0241)$. For $500 \mathrm{KHz}, 1 \mathrm{mM}$ is significantly higher than $2 \mathrm{mM}(\mathrm{p}=0.0017)$ and $2 \mathrm{mM}$ is significantly higher than $4 \mathrm{mM}(\mathrm{p}=0.0194)$. For $1000 \mathrm{KHz}, 1 \mathrm{mM}$ is significantly higher than $2 \mathrm{mM}(\mathrm{P}=0.0008)$ and $2 \mathrm{mM}$ is significantly higher than $4 \mathrm{mM}(\mathrm{p}=0.0193)$. 


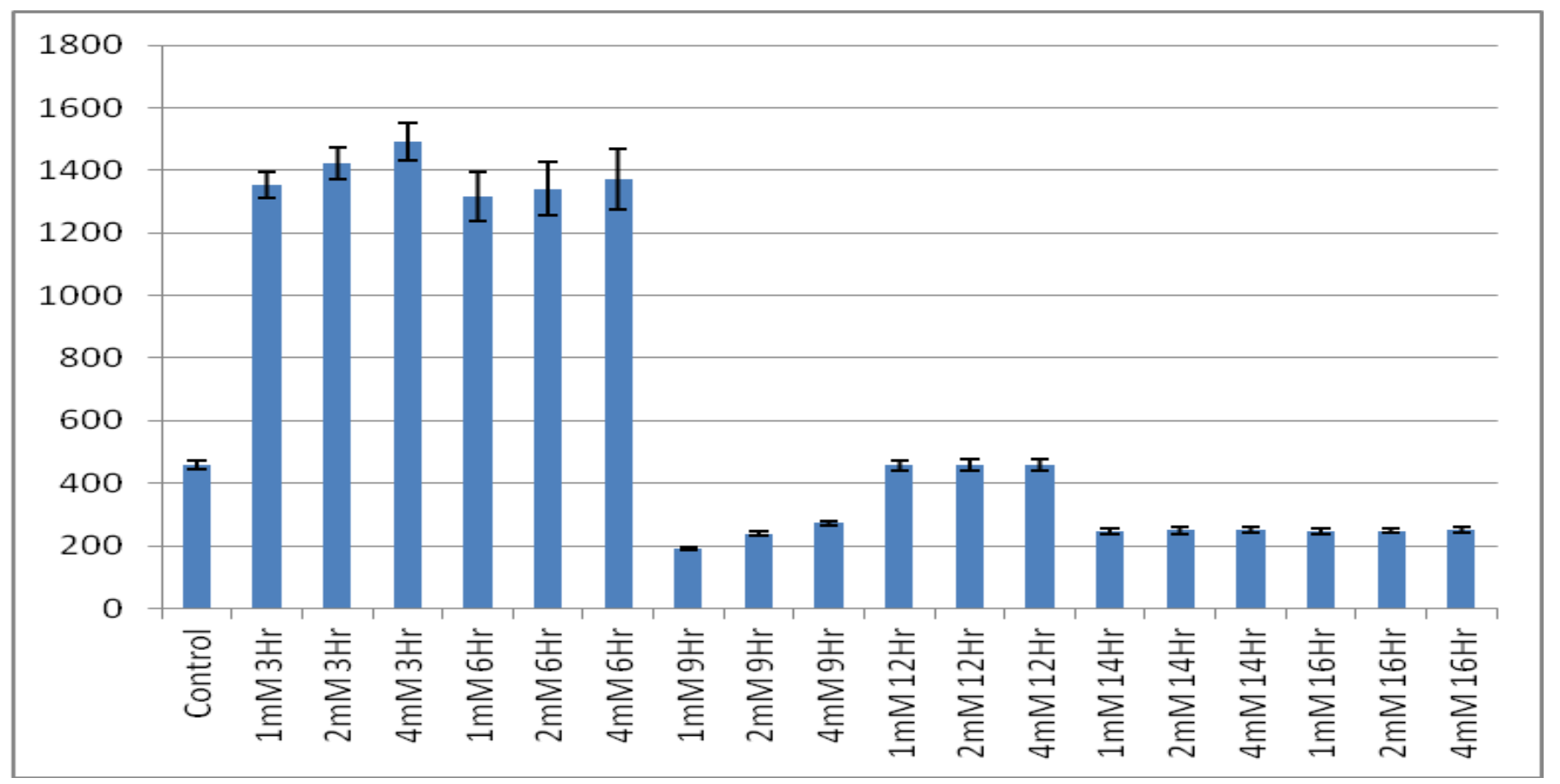

Figure 6. Plasma resistance $R_{p}(\Omega)$ for blood exposed to three different doses of uranyl acetate $(1,2$ and $4 \mathrm{mM})$ for time interval $(0-16 \mathrm{Hr})$.

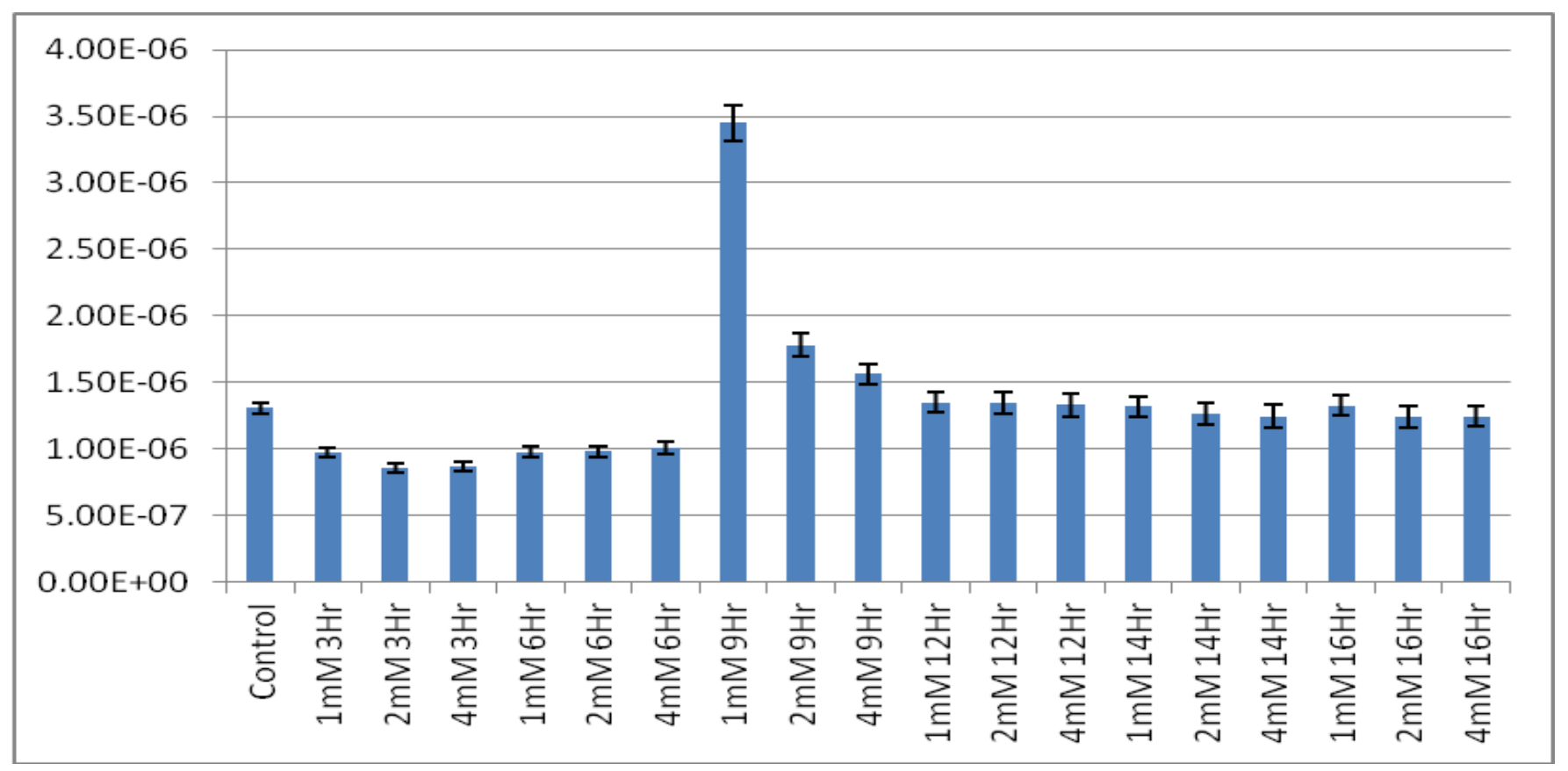

Figure 7. Membrane capacitance $C_{m}(F)$ for blood exposed to three different doses of uranyl acetate $(1,2$ and $4 \mathrm{mM})$ for time interval $(0-16 \mathrm{Hr})$. 


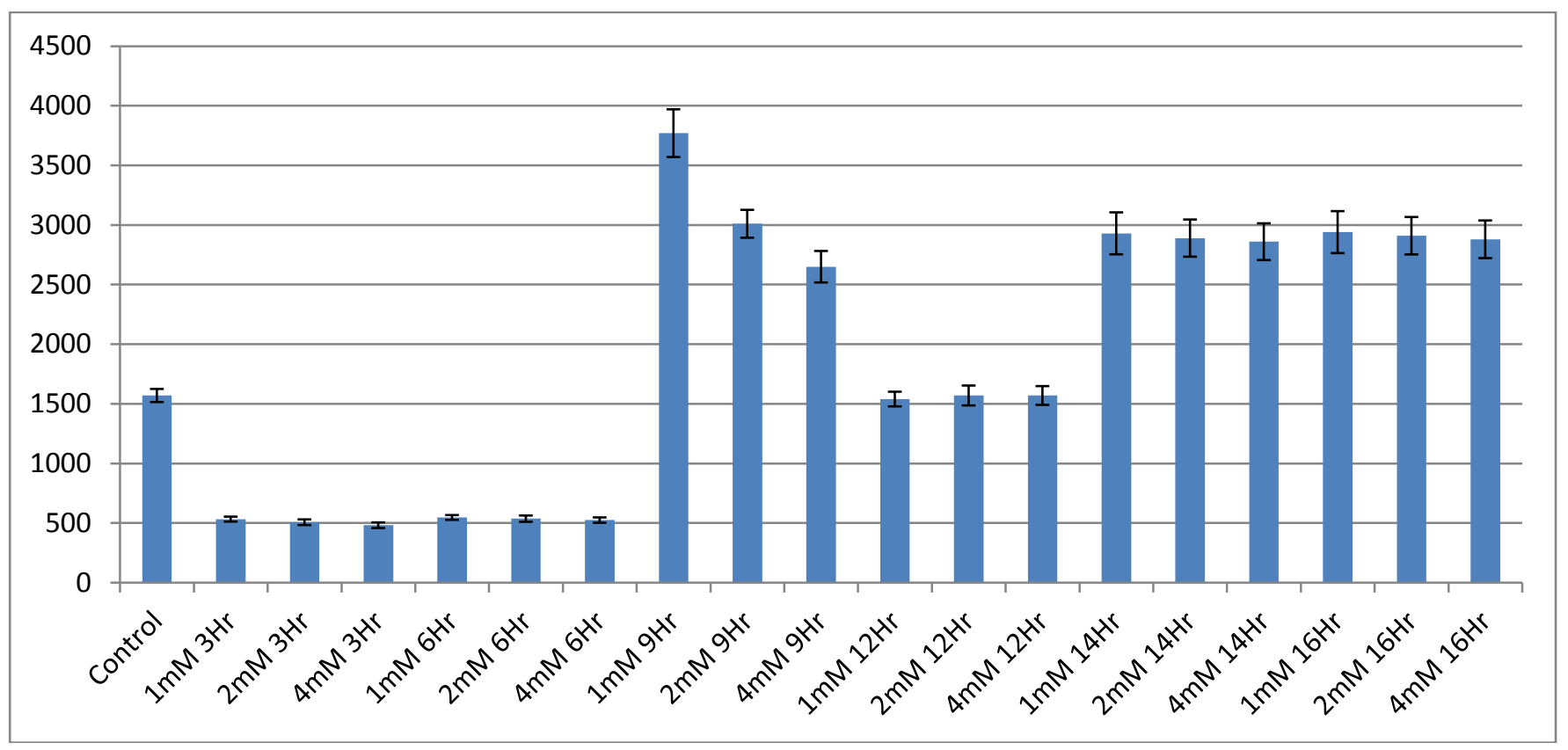

Figure 8. Dielectric loss $\left(\varepsilon^{\prime \prime}\right)$ at $25 \mathrm{KHz}$ for blood exposed to three different doses of uranyl acetate $(1,2$ and $4 \mathrm{mM})$ for time interval $(0-16 \mathrm{Hr})$.

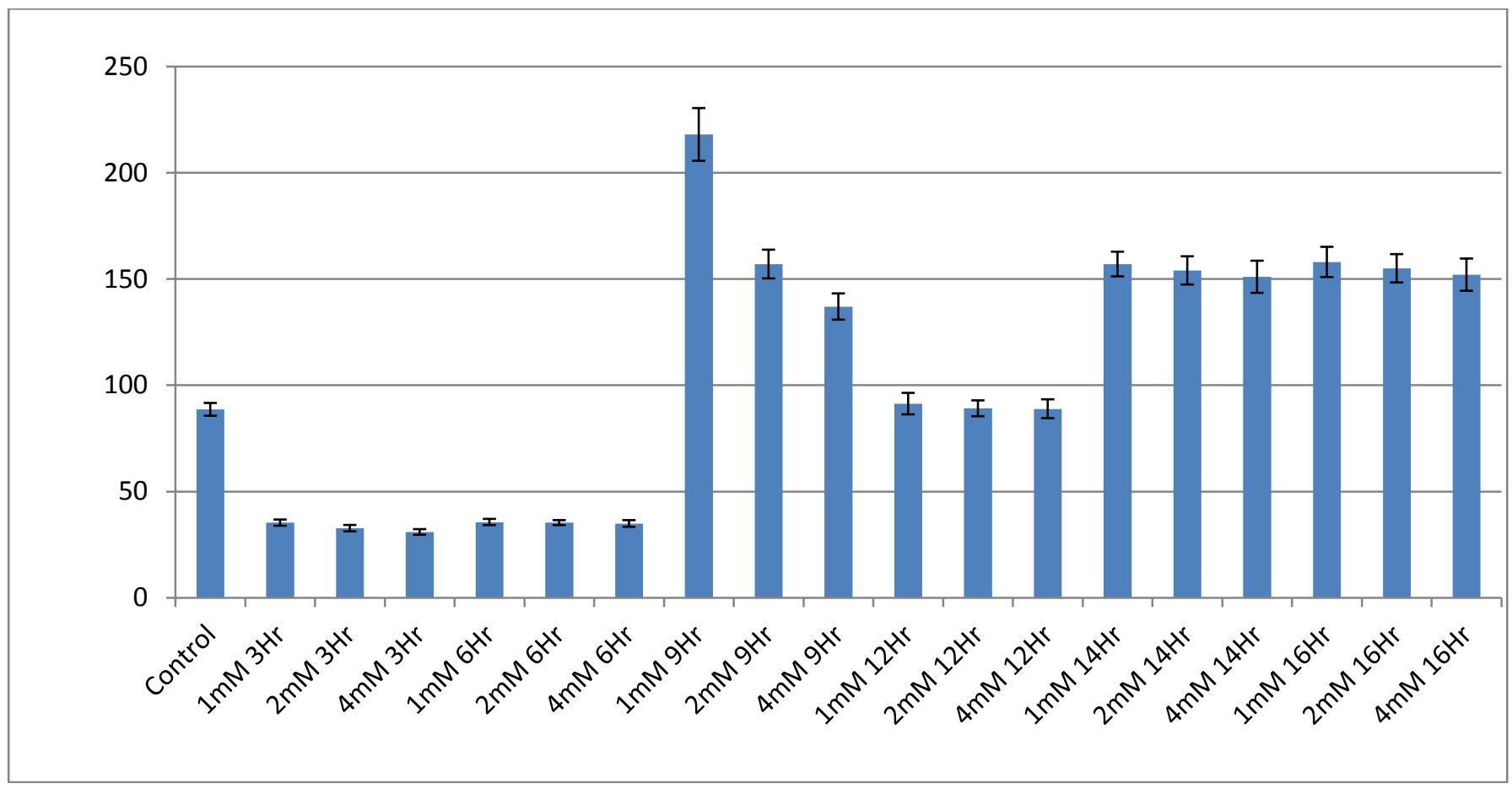

Figure 9. Dielectric loss $\left(\varepsilon^{\prime \prime}\right)$ at $500 \mathrm{KHz}$ for blood exposed to three different doses of uranyl acetate (1, 2 and $\left.4 \mathrm{mM}\right)$ for time interval $(0-16 \mathrm{Hr})$. 


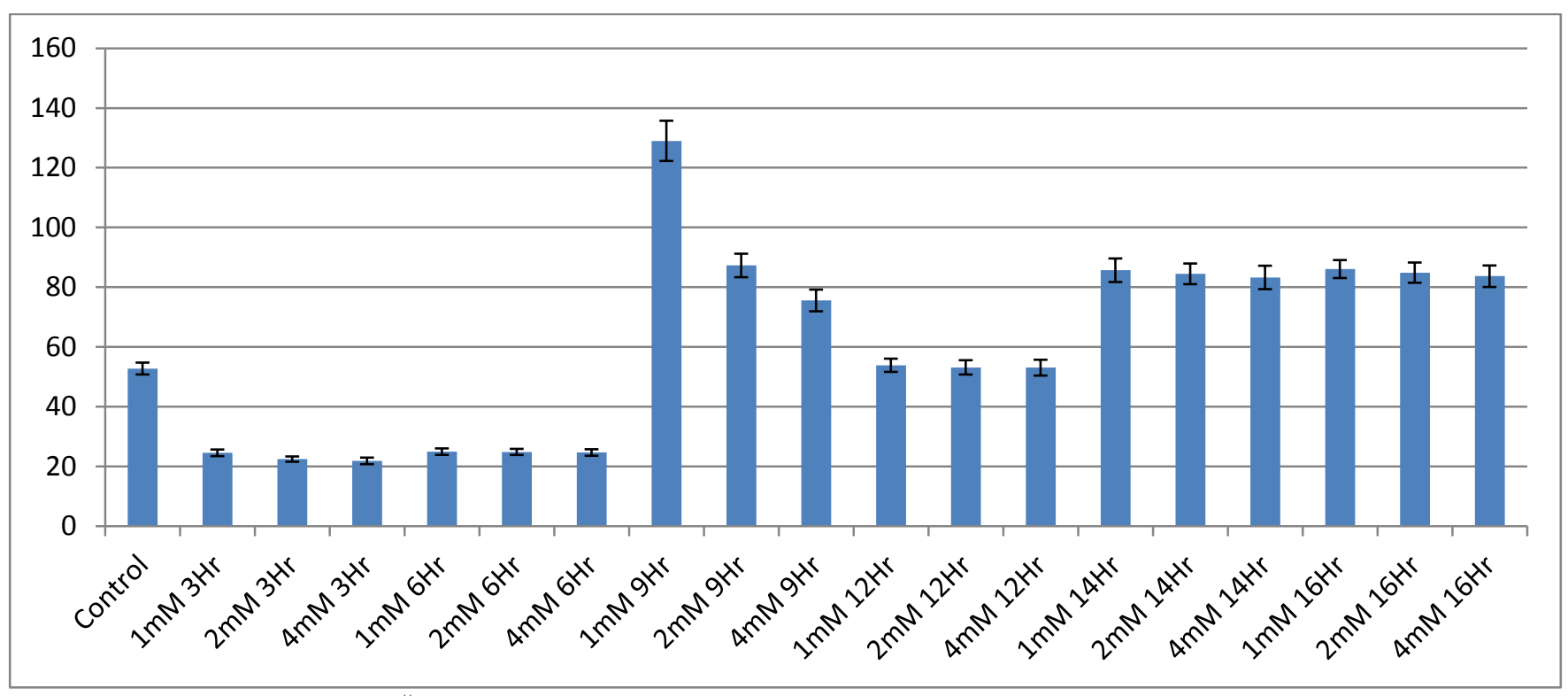

Figure 10. Dielectric loss $\left(\varepsilon^{\prime \prime}\right)$ at $1000 \mathrm{KHz}$ for blood exposed to three different doses of uranyl acetate $(1,2$ and 4 $\mathrm{mM})$ for time interval $(0-16 \mathrm{Hr})$.

\section{Discussion}

Many authors before could not obtain any DU dose relationship on blood. A 91 days exposure to uranyl nitrate hexahydrate in drinking water $(0.96,4.8,24,120$, or $600 \mathrm{mg}$ uranyl nitrate/L) was shown to alter several hematological parameters in rats [9]. Both hemoglobin concentrations and red blood cells were significantly increased in females given 24 mg uranyl nitrate/L. Mean corpuscular hemoglobin values were slightly higher in female rats given 24, 120, or $600 \mathrm{mg}$ uranyl nitrate/L. Serum glucose levels were higher in male rats at 24 and 600mg uranyl nitrate/L. Serum sodium levels were decreased in female rats given $24 \mathrm{mg}$ uranyl nitrate/L. No significant changes were observed in erythrocytes in any of the treatment groups. Despite these observations, there were no trends or dose-related effects on hematological parameters of uranyl nitrate given to rats in drinking water. This study was repeated in New Zealand white rabbits. While there were several changes in hematological parameters, none were dose related [7].

Also using electrical properties to obtain radiation dose related relationship is not always useful. A study shows that up to $508 \mathrm{~K}$, behavior of the $\gamma$-irradiated bone electrical conductivity does not depend on the dose value. For doses 0 , 10,50 and $100 \mathrm{kGy}$, curves change their slope at a temperature of about $508 \mathrm{~K}$ and not below [15].

Since uranyl acetate is prepared from DU it emits $\alpha$ particles, and the main effect mechanism when it enters the body is the production of free radicals [16], so it can be expected that as the concentration increases, the effect increases with time but it is not the case. The oxidation of cell membrane and accumulation of hydrogen peroxide is time dependent, also the antioxidant enzymes work against the hyper-oxidation and damage of the cells and that also is time dependent.

The permittivity is a measure of its polarizability in the electric field. It is related to the structural arrangement of the lipid bilayer and also to the conformation and localization of proteins in the membrane [17]. This polarization does not occur instantaneously, and the associated time constant is called the relaxation time $\tau$ [18]. All these kinetics that make the measuring of the effect of different doses after certain fixed time may not provide sufficient information on dose effect relationship.

The dielectric characteristics of a material include both conductive and capacitive properties [19]. The conductivity depends on the dynamical ionic transport through the membrane, so it is a 
measure of the permeability of the cell membrane [20]. So predicting that the oxidation of the cell membranes by accumulating free radicals will result in increase the membrane pores which in turn increase permeability, relative permittivity and conductivity cannot be applied. Electrical conductivity depends on the number of free charge carriers and their mobility. The polymer chain scission generated during irradiation hinders the charge transportation, decreasing the mean free path of charge carriers and, as a result, diminishing charge mobility. Free charge carriers can be trapped during irradiation, diminishing their number despite the extra charge carriers generated by radiation. In such a way, electrical conductivity decreases with increasing dose.

The capacitance determines the amount of charge that can be stored across a membrane when a cell is exposed to an electric field. Its value is strongly dependent on the level of folding of the cell membrane [21]. The dielectric loss is proportional to the total concentration of dipoles in the material and their dipole moment, irrespective to the distribution of the irrelaxation times [22]. Each subunit in the membrane acts as capacitor $\left(\mathrm{C}_{\mathrm{m}}\right)$, their effective capacitance is determined by the irrelative positions. These events change by time, so we followed up until the appropriate time of measuring was detected.

\section{Conclusion}

In this paper we think that measuring many electrical parameters at different time intervals can help in detecting the useful parameters and the appropriate time of measuring to detect the dose related relationship. We select 25, 500 and $1000 \mathrm{KHz}$ to detect the changes in the $\beta$ dispersion which is known as a structural relaxation and occurs at the radio frequency range $10 \mathrm{kHz}$ to $10 \mathrm{MHz}$. The impedance amplitude of blood is almost constant at frequencies below 100 $\mathrm{kHz}$, since the electric current passes through the plasma only, while the membranes of blood cells act as insulators. When the frequency is increased to about $200 \mathrm{kHz}$, the impedance will decrease with an increase in frequency since the membranes of the blood cells start to conduct.

\section{References}

1. Arnault, E. ; Doussau, M. ; Pesty, A.; Gouget, B.; Meeren, A.; Fouchet, P.; Lefevre, B. Natural uranium disturbs mouse folliculogenesis in vivo and oocyte meiosis in vitro, Toxicology, 2008, 247 (2-3), 80-87. Doi: 10.1016/j.tox.2008.02.006.

2. Gueguen, Y. ; Grandcolas, L.; Baudelin, C.; Grison, S.; Tissandie, E.; Jourdain, J.R.; Paquet, F.; Voisin, P.; Aigueperse, J.; Gourmelon, P.; Souidi, M. Effect of acetaminophen administration to rats chronically exposed to depleted uranium, Toxicolcology, 2007, 229 (1-2), 62-72. Doi: 10.1016/j.tox.2006.10.006.

3. May, L.; Heller, J.; Kalinsky, V.; Ejnik, J.; Cordero, S.; Oberbroekling, K. Military deployment human exposure assessment: urine total and isotopic uranium sampling results, Journal of Toxicology Environmental Health A, 2004, 67 (8-10), 697-714. Doi : $10.1080 / 15287390490428189$.

4. Cantaluppi, C.; Degetto, S. Civilian and military uses of depleted uranium: Environmental and health problems, Annali di Chimica, 2000, 90 (11-12), 665-676.

5. Lide, R.D. Handbook of Chemistry and Physics, 87 ed., Boca Raton, FL: CRC Press, United Kingdom, 1998.

6. Elena, S.; Craft, A.W. ; Flaherty, M.M. ; Garofolo, M.C.; Rincavage, H.L.; AbouDonia, M.B. Depleted and natural Uranium: Chemistry and toxicological effects, Journal of Toxicology Environmental Health Part B, 2004, 7 (4), 297-317. Doi: 10.1080/10937400490452714.

7. Gilman, A.P. ; Villeneuve, D.C.; Secours, V.E.; Yagminas, A.P.; Tracy, B.L. ; Quinn, J.M.; Valli, V.E.; Moss, M.A. Uranyl nitrate: 91-Day toxicity studies in the New Zealand white rabbits, Toxicological Sciences, 1998, 41 (1), 129-137. Doi : 10.1093/toxsci/41.1.129.

8. Gilman, A.P. ; Moss, M.A.; Villeneuve, D.C.; Secours, V.E.; Yagminas, A.P.; Tracy, B.L.; Quinn, J.M.; Long, G.; Valli, V.E. Uranyl nitrate: 91-Day exposure and recovery studies in the New Zealand white rabbit, 
Toxicological Sciences, 1998, 41(1), 138151. Doi: 10.1093/toxsci/41.1.138.

9. Gilman, A.P. ; Villeneuve, D.C.; Secours, V.E.; Yagminas, A.P.; Tracy, B.L.; Quinn, J.M. ; Valli, V.E.; Willes, R.J.; Moss, M.A. Uranyl nitrate: 28-Day and 91-day toxicity studies in the Sprague-Dawley rat, Toxicological Sciences, 1998, 41 (1), 117128.

10. Zimmerman, K.L.; Barber, D.S.; Ehrich, M.F.; Tobias, L.; Hancock, S.; Hinckley, J.; Binder, E.M.; Jortner, B.S. Temporal clinical chemistry and microscopic renal effects following acute uranyl acetate exposure, Toxicologic Pathology, 2007, 35(7), 10001009. Doi : 10.1080/01926230701748446.

11. Pop, G. ; Hop, W.J.; Moraru, L.M.; vanderJagt, Q.J.; Dekkers, D. ; Chang, Z.; Gijsen, F.J.; Duncker, D.J.; Slager, C.J. Blood electrical impedance closely matches whole blood viscosity as parameter of hemorheology and inflammation, Applied Rheolgy, 2003, 13(6), 305-312.

12. Sezdi, M. ; Bayık, M. ; Ulgen, Y. Storage effects on the Cole-Cole parameters of erythrocyte suspensions, Physiological Measurement, 27(7), 623-635. Doi : 10.1088/0967-3334/27/7/006.

13. Carriere, M.; Avoscan, L.; Collins, R.; Carrot, F.; Khodja, H.; Ansoborlo, E.; Gouget, B. Influence of uranium speciation on normal rat kidney (NRK-52E) proximal cell cytotoxicity, Chemical Research in Toxicology, 2004, 17(3), 446-452. Doi: 10.1021/tx034224h.

14. Zhao, T.; Jacobson, B. ; Ribbe, T. Triplefrequency method for measuring blood impedance, Physiological Measurement,1993, 14 (2), 145-156. Doi : 10.1088/0967$3334 / 14 / 2 / 006$.

15. Kubisz, L. The effect of $\gamma$-irradiation on the temperature dependence of D.C. electrical conductivity of dry bone, International
Journal of Biological Macromolecules, 1999, 26 (1), 77-81. Doi : 10.1016/S01418130(99)00067-7.

16. A. Periyakaruppan, F. Kumar, S. Sarkar, C.S. Sharma, G.T. Ramesh, Uranium induces oxidative stress in lung epithelial cells, Arch. Toxicol. 81 (2007) 389-395. Doi: 10.1007/s00204-006-0167-0.

17. Bonincontro, A. ; Cametti, C. ; Rosi, A.; Sportelli, L. Electrical parameters of erythrocyte membranes deduced from radio wave conductivity measurements, Journal of Membrane Science, 1989, 41, 345-354. Doi: 10.1016/S0376-7388(00)82413-8.

18. Martinsen, I.G.; Grimnes, S. ; Schwan, H.P. Interface Phenomena and Dielectric Properties of Biological Tissue, Encyclopedia of Surface and Colloid Science, Marcel Dekker, New York, 2002.

19. Reilly, J.P. Applied Bioelectricity: From Electrical Stimulation to Electro- pathology, Springer, New York ,1998, pp 14. Doi: 10.1007/978-1-4612-1664-3.

20. Pethig, R. ; Talary, M.S, Dielectrophoretic detection of membrane morphology changes in Jurkat T-cells undergoing etoposideinduced apoptosis, IET Nanobiotechnology, 2007, 1 (1), 2-9. Doi : 10.1049/ietnbt:20060018.

21. Gascoyne, P.R. ; Vykoukal, J.V. Dielectrophoresis-based sample handling in general-purpose programmable diagnostic instruments, Proceedings of the IEEE, 2004, 92 (1) 22-42. Doi : 10.1109/JPROC.2003.820535.

22. Pethig, R. Dielectric and electronic properties of biological materials, John Wiley and sons, New York, 1979. 